\title{
TU/ Emonown

\section{Crystallization of sodium sulfate in porous media by drying at a constant temperature}

\section{Citation for published version (APA):}

Saidov, T. A., Pel, L., \& van der Heijden, G. H. A. (2015). Crystallization of sodium sulfate in porous media by drying at a constant temperature. International Journal of Heat and Mass Transfer, 83, 621-628.

https://doi.org/10.1016/j.ijheatmasstransfer.2014.12.043

\section{Document license: \\ TAVERNE}

DOI:

10.1016/j.ijheatmasstransfer.2014.12.043

Document status and date:

Published: 01/04/2015

\section{Document Version:}

Publisher's PDF, also known as Version of Record (includes final page, issue and volume numbers)

\section{Please check the document version of this publication:}

- A submitted manuscript is the version of the article upon submission and before peer-review. There can be important differences between the submitted version and the official published version of record. People interested in the research are advised to contact the author for the final version of the publication, or visit the $\mathrm{DOI}$ to the publisher's website.

- The final author version and the galley proof are versions of the publication after peer review.

- The final published version features the final layout of the paper including the volume, issue and page numbers.

Link to publication

\section{General rights}

Copyright and moral rights for the publications made accessible in the public portal are retained by the authors and/or other copyright owners and it is a condition of accessing publications that users recognise and abide by the legal requirements associated with these rights.

- Users may download and print one copy of any publication from the public portal for the purpose of private study or research.

- You may not further distribute the material or use it for any profit-making activity or commercial gain

- You may freely distribute the URL identifying the publication in the public portal.

If the publication is distributed under the terms of Article $25 \mathrm{fa}$ of the Dutch Copyright Act, indicated by the "Taverne" license above, please follow below link for the End User Agreement:

www.tue.nl/taverne

Take down policy

If you believe that this document breaches copyright please contact us at:

openaccess@tue.nl

providing details and we will investigate your claim. 


\title{
Crystallization of sodium sulfate in porous media by drying at a constant temperature
}

\author{
T.A. Saidov*, L. Pel, G.H.A. van der Heijden \\ Department of Applied Physics, Eindhoven University of Technology, P.O. Box 513, 5600 MB Eindhoven, The Netherlands
}

\section{A R T I C L E I N F O}

\section{Article history:}

Received 8 March 2012

Received in revised form 14 December 2014

Accepted 15 December 2014

Available online 9 January 2015

\section{Keywords:}

Drying

Ion transport crystallization

Sodium sulfate

\begin{abstract}
A B S T R A C T
Sodium sulfate is generally seen as one of the most destructive salts in the weathering of historical objects. The crystallization which causes the damage can either be induced by drying and/or cooling of a salt solution in a porous material. In this study we have studied the crystallization of sodium sulfate during the drying of various porous materials at different temperatures. The experiments were conducted such that the Peclet number was smaller than one, i.e., the ion transport in the porous material is dominated by diffusion. The results show that at temperatures above $22{ }^{\circ} \mathrm{C}$ during the drying the anhydrous crystal phase of sodium sulfate, i.e., thenardite is eventually formed. Below $22{ }^{\circ} \mathrm{C}$ heptahydrate crystal phase is formed, which is metastable with respect to the corresponding mirabilite solubility.
\end{abstract}

(C) 2014 Elsevier Ltd. All rights reserved.

\section{Introduction}

Our cultural heritage all over the world is under constant threat from its environment. Salts are widely recognized as a major cause for the loss of many historical objects, such as statues, buildings, and other artworks [1-3]. The damage caused by soluble salts is generally due to their accumulation at the surface by drying and subsequent crystallization. These salts are observed at the surface, i.e., as efflorescence, or just below the surface, i.e., as sub-florescence. Here, they may cause structural damages, e.g., delamination, surface chipping, or disintegration, with consequent loss of detail. In order to prevent damage induced by crystallization we must understand the processes causing the salt crystallization and know the preferred crystallization phase which is formed. The critical issue is not the formulation of transport equations and constitutive relations, but the lack of adequate and reliable experimental data.

Sodium sulfate is generally seen as one of the most destructive salts in the weathering of historical objects. A sodium sulfate solution can be easily supersaturated with respect to mirabilite solubility concentration [4]. As shown by Correns, a salt in contact with its supersaturated solution can produce a crystallization pressure, which can give rise to mechanical damage [5-7].

The phase diagram of sodium sulfate is given in Fig. 1. Two wellknown phases are mirabilite $\left(\mathrm{Na}_{2} \mathrm{SO}_{4} \cdot 10 \mathrm{H}_{2} \mathrm{O}\right)$, anhydrous thenardite $\left(\mathrm{Na}_{2} \mathrm{SO}_{4}\right)$ and its metastable phase, i.e., the so-called phase III [7-10]. There is also a metastable phase, the heptahydrate

\footnotetext{
* Corresponding author.
}

$\left(\mathrm{Na}_{2} \mathrm{SO}_{4} \cdot 7 \mathrm{H}_{2} \mathrm{O}\right)$, which is often forgotten. Indeed, in 1850 Lövel already observed that from a supersaturated solution by cooling the metastable heptahydrate instead of stable decahydrate will crystallize out [8]. His observations are in accordance with Ostwald's rule of stages [11]. In 1897 Ostwald reported a study of the nucleation of crystals in droplets, in which he observed that some compounds first nucleated in a less-stable crystal structure and then later on converted into a more-stable polymorph. This observation was generalized as the "rule of stages", i.e., the less-stable polymorph will nucleate first, and later converts into the most stable polymorph, sometimes via structures of intermediate stability.

In 1915 Hartley et al. [9] showed that in 90\% of the cooling experiments of sodium sulfate heptahydrate was formed, which confirmed the earlier observations by Lövel [8] and also Coppet [10]. In 2004 Rijniers et al. [12] were the first to show that heptahydrate can also be formed in porous materials during cooling. By Lövel [8], Liversidge [13], and more recently by Saidov et al. [14] as part of general study on sodium sulfate in porous media [15,16], it was shown that heptahydrate will also be formed upon crystallization by evaporation of a bulk solution, i.e., creating a supersaturation by removal of water. In this paper we will concentrate on the crystallization of sodium sulfate in porous materials by drying at a constant temperature. We will first give a short introduction of the ion transport and accumulation during drying, followed by a description of the NMR setup used for the non-destructive measurements of the moisture and ion transport during drying. The results of the drying experiments will be discussed, followed by conclusions. 


\section{Drying experiments}

During the drying of a sample saturated with a salt solution, the liquid moisture is transported to the surface where it can leave the material by evaporation. As ions cannot leave the material, the ion concentration will increase and as it reaches the solubility saturation of a certain crystal phase the crystallization will start. By measuring the ion concentration in a porous material we can identify which crystalline phase of sodium sulfate is being formed.

The ions in the solution will be transported by two processes, i.e., advection with the moisture and diffusion within the moisture. Hence there will be a competition between advection that transports ions towards the surface and diffusion that will try to level off the gradients in the ion concentration. This competition between these two processes can be characterized by a Peclet number (Pe). On a macroscopic level, i.e., in a porous material the Peclet number is given by [17]:

$P e \equiv \frac{|U| L}{D}$

where $L[\mathrm{~m}]$ is the length of the sample, $D\left[\mathrm{~m}^{2} \mathrm{~s}^{-1}\right]$ the diffusion coefficient of salt ions in a porous material, which is given by $D=D_{\text {bulk }} T^{*}$ where $T^{*}$ is tortuosity and $D_{\text {bulk }}$ the bulk diffusion coefficient of salt ions, and $U\left[\mathrm{~m} \mathrm{~s}^{-1}\right]$ the fluid velocity. Hence, for $P e \ll 1$ diffusion dominates and the ion-profiles will be uniform, whereas for $P e \gg 1$ advection dominates and ions will accumulate at the drying surface.

\section{Materials and methods}

Nuclear Magnetic Resonance (NMR) has been used to measure the spatial distribution of the ion and moisture concentration inside a porous material. With NMR it is possible to image specific nuclei spatially, e.g., ${ }^{1} \mathrm{H}$ and ${ }^{23} \mathrm{Na}$. The apparatus used in this study has an iron-cored electromagnet generating a field of $0.73 \mathrm{~T}$. An extensive description of this setup can be found in $[18,19]$. In this setup (see Fig. 2) Anderson gradient coils are used to generate a constant gradient of $0.3 \mathrm{~T} / \mathrm{m}$, resulting in a one-dimensional resolution of the order of $1 \mathrm{~mm}$. A Faraday shield has been added to suppress the effect of dielectric changes [19]. By an electrically operated switch the LC circuit of the insert can be tuned to $30.8 \mathrm{MHz}$ for ${ }^{1} \mathrm{H}$ or to $8.1 \mathrm{MHz}$ for ${ }^{23} \mathrm{Na}$ imaging.

The cylindrical sample with a diameter of $20 \mathrm{~mm}$ is moved vertically through the magnet with the help of a stepper motor. The sample is sealed at all sides except the top over which air with

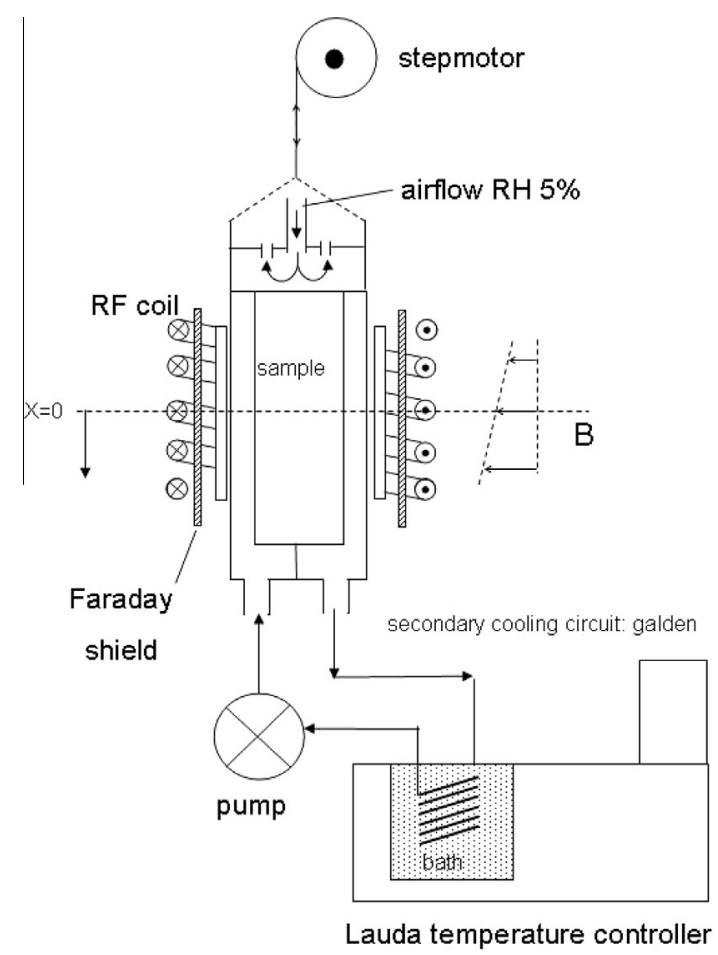

Fig. 2. The experimental setup used for measuring the moisture and ion content during drying with NMR. The sample is placed in a temperature controlled sample holder and air is blown over the top of the sample.

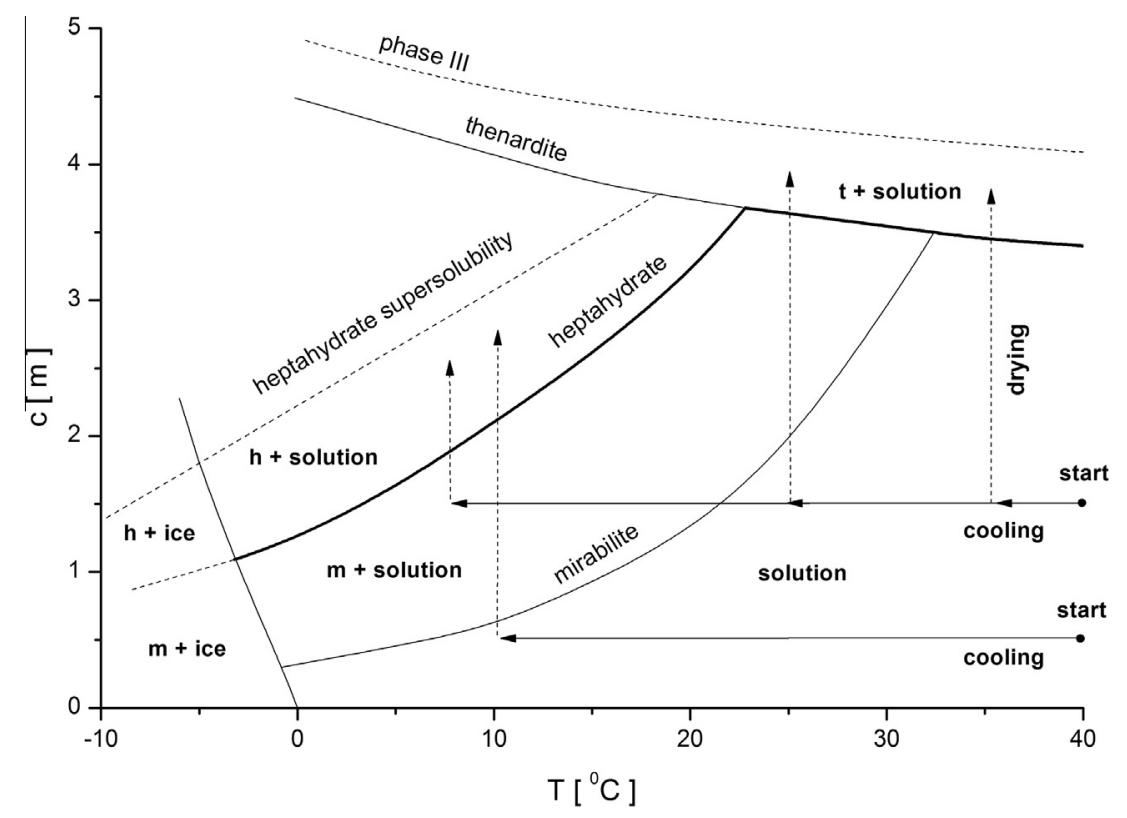

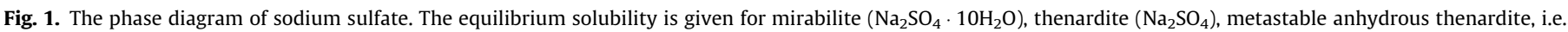

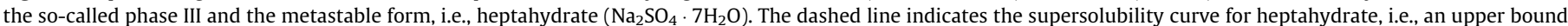

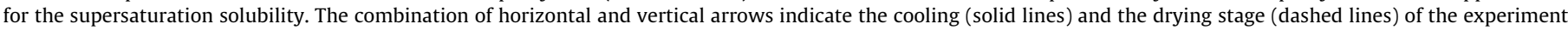
performed. 
a relative humidity of $5 \%$ is blown. In this way a one-dimensional drying process is created. The temperature of the sample holder can be accurately controlled by flowing a fluorinated cooling liquid, Galden $\odot$, through a heat exchanger in the wall of the sample holder. Since this fluid contains no ${ }^{1} \mathrm{H}$ or ${ }^{23} \mathrm{Na}$, it yields no unwanted background signal in our NMR measurements. The air temperature of the air flow is not controlled.

It takes $60 \mathrm{~s}$ to determine the moisture content at one position. Due to the lower relative NMR sensitivity of ${ }^{23} \mathrm{Na}$ it takes approx. 4 min to measure the sodium content with a comparable signal-to-noise ratio. Because of the NMR echo times used in the experiments ( $\mathrm{TE}=340 \mu \mathrm{s}$ ) only the ${ }^{23} \mathrm{Na}$ nuclei in the solution are measured, i.e., no signal is obtained from sodium sulfate crystals. Hence from the ${ }^{23} \mathrm{Na}$ signal and the moisture signal the sodium sulfate solution concentration can be calculated. Measuring an entire concentration profile for a sample with a length of $50 \mathrm{~mm}$ takes about $2 \mathrm{~h}$. Since the typical time of a drying experiment is several days, the variation of the concentration profile during a single scan can be neglected.

The experiments were performed on three types of common building materials with different pore size distributions: fired-clay brick (porosity 35\%), Indiana lime stone (porosity 12\%) and Cordova Cream lime stone (porosity $16 \%$ ) see Table 1 . The samples, initially saturated with a $1.5 \mathrm{~m}[\mathrm{~m}=$ mole $/ \mathrm{kg}]$ sodium sulfate solution at $40^{\circ} \mathrm{C}$, were placed in the NMR and then cooled to the desired temperature at which drying experiments were performed, i.e., 35,25 and $7.5^{\circ} \mathrm{C}$ (see also Fig. 1). At that moment, the drying experiments were started with a low airflow of $5 \%$ relative humidity in order to have the experiments in the drying regime where $P e \ll 1$, i.e., making certain there are no large concentration gradients present in the sample. In addition we have also conducted an additional experiment using fired-clay brick where $P e \gg 1$ at $10^{\circ} \mathrm{C}$ for a solution of $0.5 \mathrm{~m}$ to see the effect of large concentration gradients on the crystallization behavior.
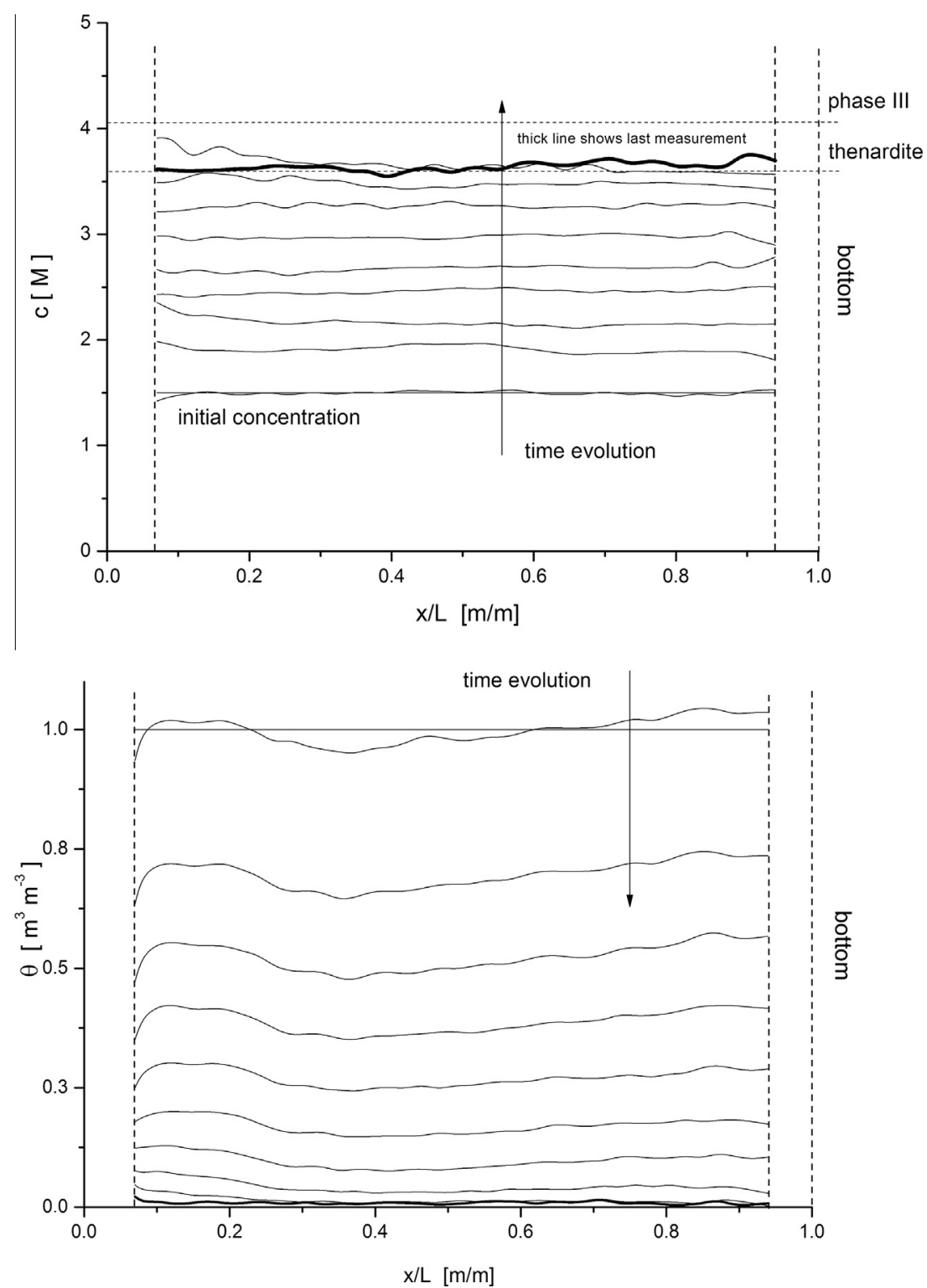

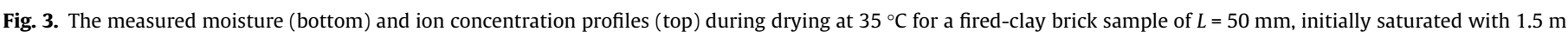

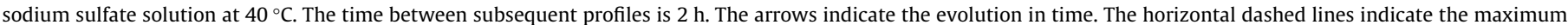
solubility for thenardite and phase III at $35^{\circ} \mathrm{C}$. The bold lines indicate the last measured profiles. 


\section{Results and discussion}

The first drying experiments were performed at a temperature of $35^{\circ} \mathrm{C}$. At this temperature, in accordance with phase diagram (see Fig. 1), two phases can be formed; the metastable anhydrous phase III and thenardite. As an example, the results of the measured moisture and ion concentration profiles for the drying of fired-clay brick are given in Fig. 3. The time between two subsequent moisture and ion profiles is $2 \mathrm{~h}$. As can be seen, as the drying starts the water content slowly decreases homogeneously and no drying front is observed. At the same time the ion concentration slowly increases throughout the whole sample up to $3.4 \mathrm{~m}$. As can be seen, the ion profiles are homogeneous indicating diffusion is dominant and hence $P e<1$. Near the drying surface we can observe a further increase of the concentration. Extrapolating this concentration profile to the drying surface we see that a maximum concentration of approximately $4.1 \mathrm{~m}$ is reached, corresponding to phase III (see phase diagram Fig. 1 for $T=35^{\circ} \mathrm{C}$ ). The next profile the concentration near the surface of the sample has dropped down to $3.4 \mathrm{~m}$ corresponding to thenardite. This indicates that at the drying surface probably first the metastable phase III is being formed, directly followed by a transformation to the thermodynamically more stable thenardite. Due to measurement time resolution of the measurements, i.e., 2 h for one profile measurement, we are unable to observe this transformation in more detail. A similar transformation from phase III to thenardite during the drying was observed by Linnow et in X-ray diffraction experiments [20]. These observations are in accordance with Ostwalds's rule of stages [11].

We have also plotted the same data in a so-called efflorescence pathway diagram (EPD) in Fig. $4[21,22]$. In an EPD, the total amount of dissolved sodium sulfate present in the solution, $c \theta$ (in moles $/ \mathrm{kg}$ ), is plotted against the average moisture content $\theta$. The total amount of $\mathrm{Na}_{2} \mathrm{SO}_{4}$ ions present in the solution, $c \theta$, and the average saturation, $\theta$, were obtained by integrating the Na profiles and the $\mathrm{H}$ profiles measured by NMR, respectively.

In such a diagram two limiting situations can be distinguished:
- Very slow drying, i.e., $P e \ll 1$. In this case, the ion profiles remain homogeneous and for some time no crystallization will occur. The average sodium sulfate concentration will slowly increase (line $A B$ ), until the concentration in the sample has reached the maximum solubility. From this point on any additional drying will result in crystallization (line $\mathrm{BC}$ ).

- Very fast drying, i.e., $P e \gg 1$. In this case (line AC), ions are directly advected with the moisture to the top of the sample and a concentration peak will build up with a very small width. If the rate of crystallization is high enough, i.e., if there are enough nucleation sites at the top to form crystals, the average $\mathrm{Na}_{2} \mathrm{SO}_{4}$ concentration in the solution in the sample itself will remain almost constant at nearly the initial concentration (line $\mathrm{AC})$.

- From any point within the region bounded by these lines only moisture removal will result in an increase of the $\mathrm{Na}_{2} \mathrm{SO}_{4}$ concentration. A decrease of $c \theta$ can only take place by crystallization. Because the transport is driven by evaporation, crystallization always involves a (small) change of $\theta$.

As can be seen the EPD diagram indicates that for this experiment initially $P e \ll 1$. This EPD also confirms that during the final stage of the drying experiment thenardite is being formed. In this diagram also the data is plotted for both Indiana limestone and Cordova Cream lime stone drying experiments. As can be seen also in these materials thenardite is formed at $35^{\circ} \mathrm{C}$ (see Fig. 4)

Table 1

The porosity, pore surface area, density and mean pore radius of the materials used in this study [18].

\begin{tabular}{llll}
\hline & $\begin{array}{l}\text { Fired- } \\
\text { clay brick }\end{array}$ & $\begin{array}{l}\text { Cordova cream } \\
\text { limestone }\end{array}$ & $\begin{array}{l}\text { Indiana } \\
\text { limestone }\end{array}$ \\
\hline Porosity [\%] & 35 & 16 & 12 \\
Pore surface $\left[10^{3} \mathrm{~m}^{2} / \mathrm{kg}\right]$ & 0.14 & 0.44 & 0.28 \\
Density $\left[\mathrm{kg} / \mathrm{m}^{3}\right]$ & 1494 & 2225 & 1263 \\
Mean pore radius $\left[10^{-6} \mathrm{~m}\right]$ & 40 & 0.6 and 50 & 60 \\
\hline
\end{tabular}

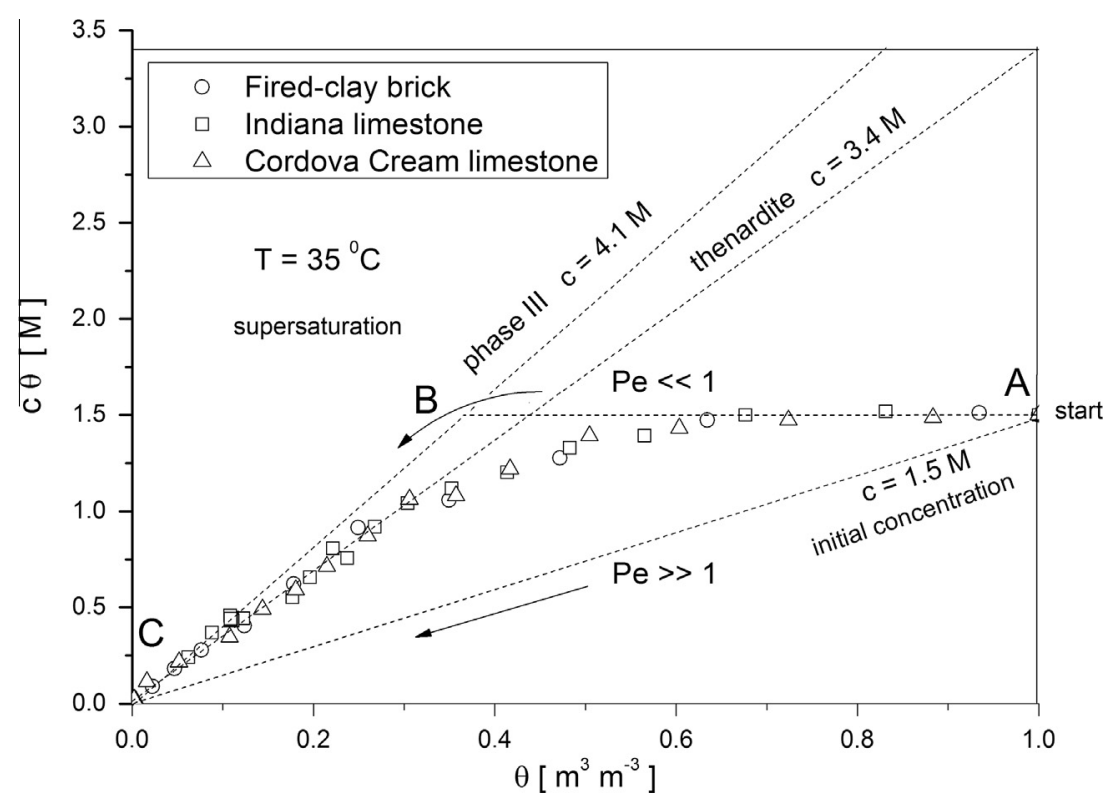

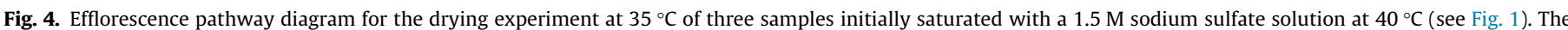

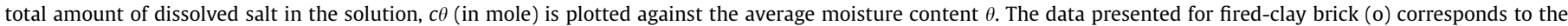
drying experiment presented in Fig. 3. 
Table 2

The estimated Pe numbers for the drying experiments at various temperatures from the measured moisture before crystallization starts (see also Eq. (3)).

\begin{tabular}{llll}
\hline Temperature & $\begin{array}{l}\text { Fired-clay } \\
\text { brick }\end{array}$ & $\begin{array}{l}\text { Cordova Cream } \\
\text { limestone }\end{array}$ & $\begin{array}{l}\text { Indiana } \\
\text { limestone }\end{array}$ \\
\hline $35{ }^{\circ} \mathrm{C}$ & 0.8 & 0.5 & 0.4 \\
$25^{\circ} \mathrm{C}$ & 0.6 & 0.2 & 0.3 \\
$7.5^{\circ} \mathrm{C}$ & 0.2 & 0.1 & $\sim 0.1$ \\
$10^{\circ} \mathrm{C}$ (fast & 40 & - & - \\
drying) & & & \\
\hline
\end{tabular}

We can also estimate the Pe-number based on the measured moisture profiles. For a porous material the conservation of water mass can be written as:

$\frac{\partial \theta}{\partial t}=-\frac{\partial}{\partial x}(\theta U)$

where $U$ is the water velocity $c$ is the concentration for sodium sulfate solution. Hence from the measured moisture profiles as a function of the time the liquid velocity at any position can be derived directly after integration:

$U(x)=-\frac{1}{\theta(x)} \frac{\partial}{\partial t} \int_{x}^{L} \theta\left(x^{\prime}\right) d x^{\prime}$

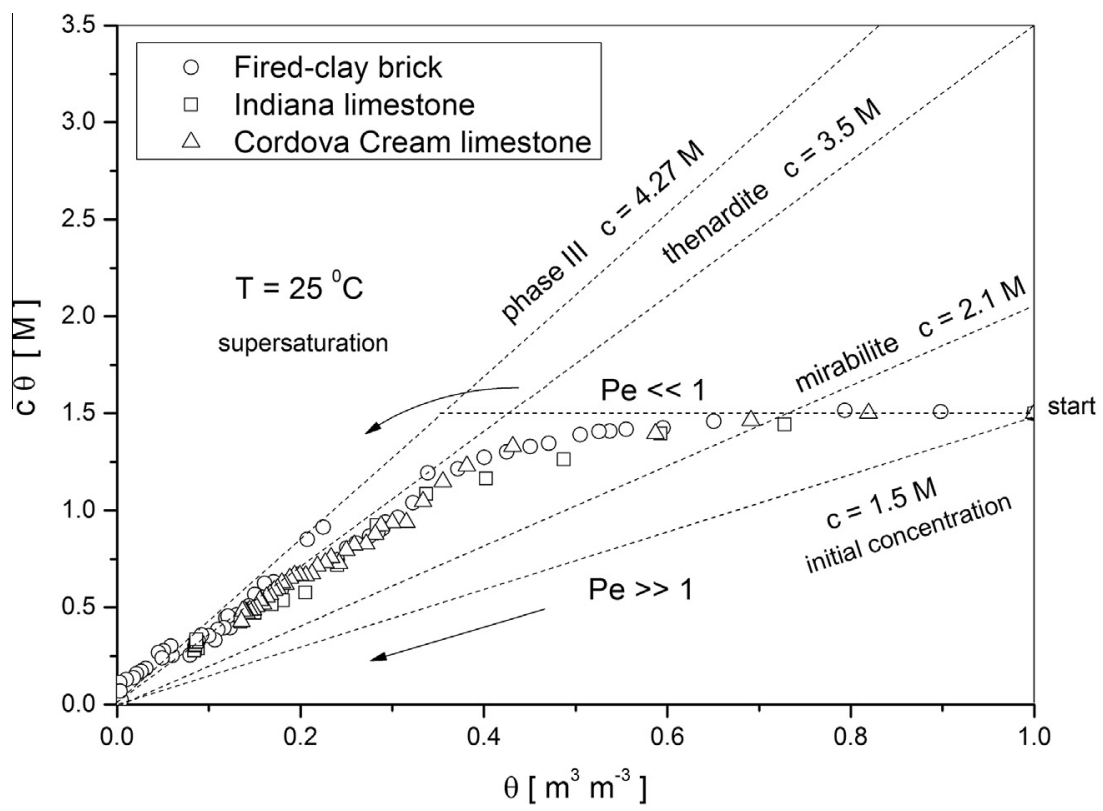

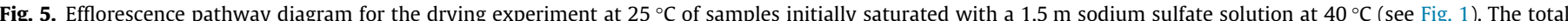

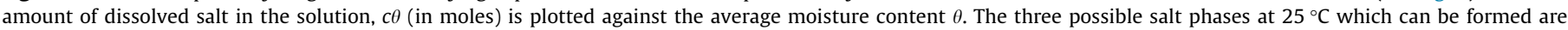
indicated by the solubility line $c=2.1 \mathrm{~m}$ for mirabilite, $c=3.5 \mathrm{~m}$ for thenardite, and $c=4.27$ for phase III.

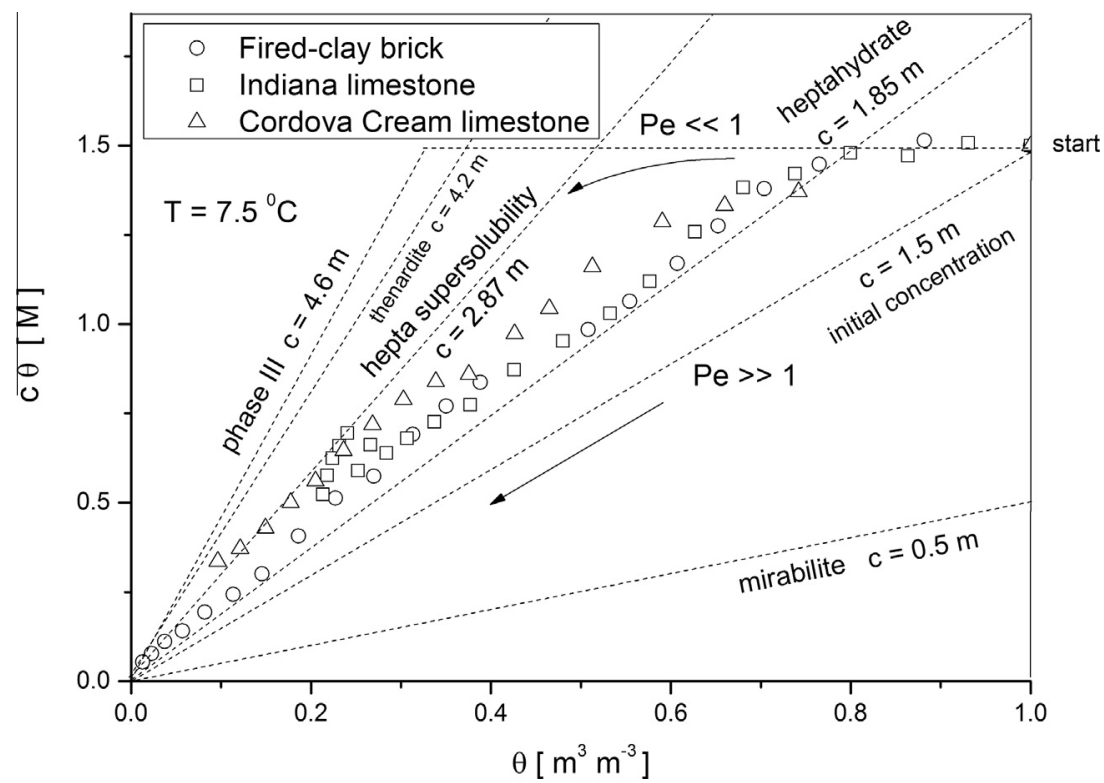

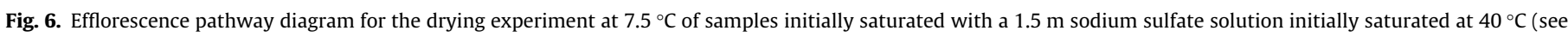

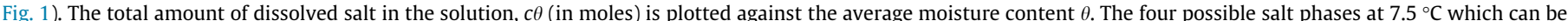

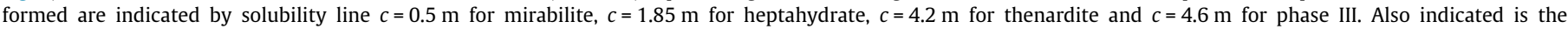
heptahydrate supersolubility line $c=2.87 \mathrm{~m}$. 
If we take as a characteristic length $L$ the length of the sample, $1 \times 10^{-9} \mathrm{~m}^{2} \mathrm{~s}^{-1}$ as a first approximation for the diffusion coefficient, $T^{*}=5$ for the tortuosity [23], we find Pe in the order of $0.2-0.8$ (see also Table 2.), i.e., $P e<1$ which is in accordance with the EPD's.

In the next set of experiments the drying of samples saturated with $1.5 \mathrm{~m}$ solution was studied at $25^{\circ} \mathrm{C}$. As can be seen from the phase diagram (see Fig. 1) three crystalline phases can be formed at this temperature: hydrated mirabilite at $2.1 \mathrm{~m}$, anhydrous thenardite at $3.5 \mathrm{~m}$ and metastable anhydrous phase III at $4.27 \mathrm{~m}$. The results of the drying experiments are plotted in an EPD as given in Fig. 5. In this case there are three boundary lines in the EPD at this temperature, i.e., one for mirabilite, phase III and one for thenardite. As can be seen from the experimental date also in this case for all drying experiments $P e<1$.

As can be seen as the drying starts the solution in all samples slowly supersaturates with respect to the solubility concentration of mirabilite, i.e., no crystallization is seen as the solution concen- tration in the samples reach the mirabilite solubility. These measurements indicate that eventually thenardite is being formed in these samples, which can again be explained by Ostwald's rule of stages, which states that the thermodynamically least favorable crystalline phases will appear first [8]. Within the time scale of this experiment no transformation to mirabilite is seen.

Next, the drying experiments of the samples saturated with $1.5 \mathrm{~m}$ were carried out at the temperature of $7.5^{\circ} \mathrm{C}$. At this temperature four crystalline phases can possibly be formed: mirabilite, heptahydrate, thenardite and phase III. In this case as the samples are cooled down initially from 40 to $7.5{ }^{\circ} \mathrm{C}$ the solution in the samples slowly get supersaturated with respect to the solubility concentration of mirabilite. So in this case the drying experiments were started with an already supersaturated sodium sulfate solution in sample, as no crystallization took place. The results of the drying experiments are given as an EPD in Fig. 6. As can be seen, as soon as the drying is started the concentration in the samples increases slowly up to the heptahydrate solubility, indicating the
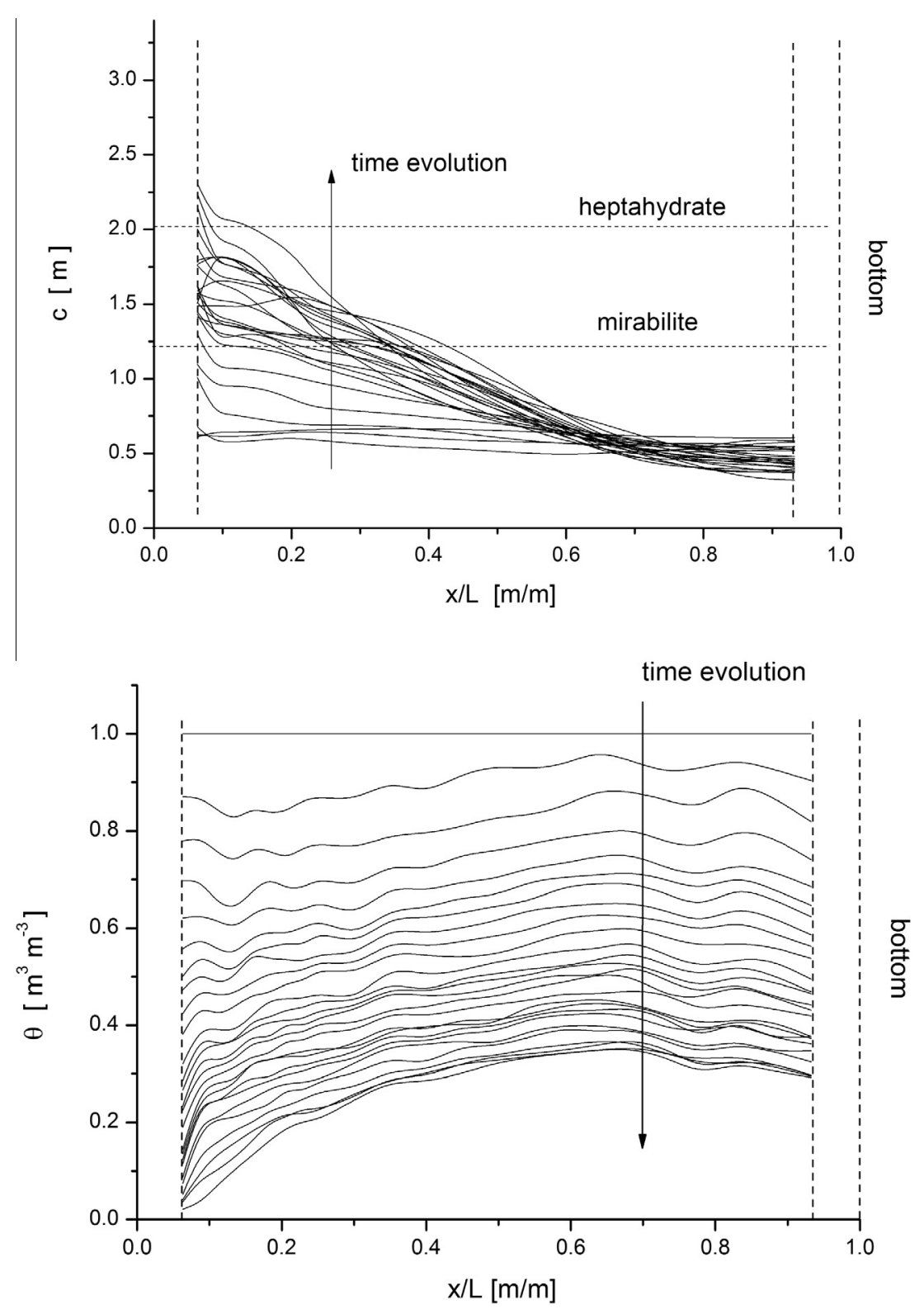

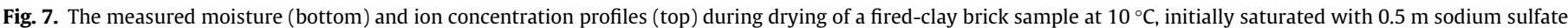

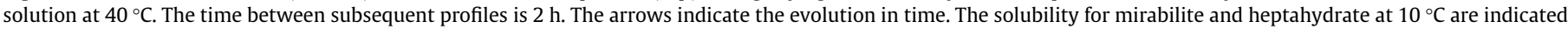
by horizontal dashed line. 


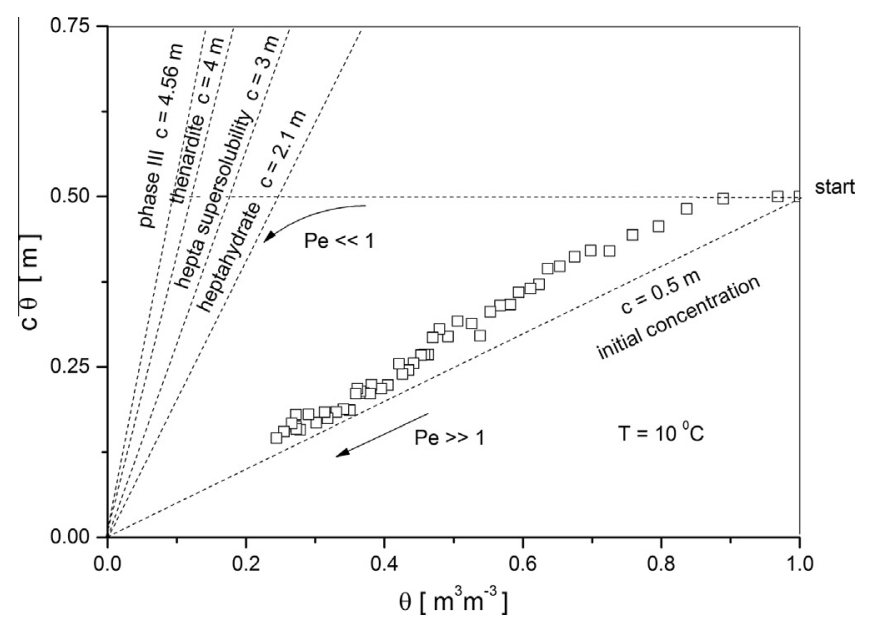

Fig. 8. Efflorescence pathway diagram for the drying experiment at $10^{\circ} \mathrm{C}$ of firedclay brick, initially saturated with a $0.5 \mathrm{~m}$ sodium sulfate solution initially saturated at $40{ }^{\circ} \mathrm{C}$ (see Fig. 1). The total amount of dissolved salt in the solution, $c \theta$ (in moles) is plotted against the average moisture content $\theta$. The four possible salt phases at $10.0^{\circ} \mathrm{C}$ which can be formed are indicated by solubility line $c=0.5 \mathrm{~m}$ for mirabilite, $c=2.1 \mathrm{~m}$ for heptahydrate, $c=4 \mathrm{~m}$ for thenardite and $c=4.56 \mathrm{~m}$ for phase III Also indicated is the heptahydrate supersolubility line $c=3 \mathrm{~m}$.

formation of heptahydrate, and the solution is supersaturated with respect to mirabilite solubility. In terms of Ostwald's rule of stages one would expect the concentration of the solution to rise further until phase III. However by Hartley et al. [9] it was shown that there is a so-called heptahydrate supersolubility line. They showed experimentally that the concentration upon cooling cannot increase anymore beyond this line. This observation of this heptahydrate supersolubility line upon cooling was also made for crystallization in porous materials by Rijniers [12], Derluyn [15], Saidov et al. $[14,16]$. Here we also observe that in the case of drying the maximum solubility for heptahydrate is limited by the heptahydrate supersolubility line and the metastable heptahydrate is being formed instead of phase III.

In order to assess if concentration gradients could influence the crystalline phase being formed an additional drying experiment with $\mathrm{Pe} \gg 1$ was done for fired-clay brick at $10^{\circ} \mathrm{C}$ for a solution of $0.5 \mathrm{~m}$. In Fig. 7, the measured moisture and salt concentration profiles are given. As can be seen, initially the fired-clay brick dries homogenous but later on moisture gradients develop towards the drying surface. From the measured salt concentration profiles it can be seen that as soon as the drying starts, ions are transported to the surface and start to accumulate. Near the surface the concentration slowly increases and the concentration near the surface slowly supersaturates with respect to mirabilite solubility. The maximum concentration reached near the surface indicates that also in this experiment heptahydrate is being formed. Hence, the drying rate and also the salt concentration gradient do not influence the salt phase which is formed. In Fig. 8 we have also plotted the corresponding EPD for this experiment. Here, it can be clearly seen that in this experiment $P e \gg 1$. Based on the measured moisture profile we estimate Pe (see Table 2), which is in accordance with the results of the EPD. Moreover this figure also indicates that the crystallization rate of heptahydrate is fast enough, i.e., there are nucleation barriers, in comparison to the ion flux towards the surface, as the data is close to the line indicating $P e \gg 1$ in this experiment.

\section{Conclusions}

In this study it has been shown that during the drying of a porous material saturated with a sodium sulfate solution the metastable sodium sulfate heptahydrate is being formed at temperatures below $22^{\circ} \mathrm{C}$. Above $22^{\circ} \mathrm{C}$ the measurements indicate that first phase III is formed, followed by rapid transition to thenardite. This crystallization of a crystal, which is initially supersaturated with respect to the equilibrium phase solubility, is in accordance with Ostwald's rule of stages. However below $22^{\circ} \mathrm{C}$, this rule of stages is applicable only for those crystal phases of which the maximum solubility is below heptahydrate supersolubility.

The experimental results show that both the internal properties of the porous materials and the drying rate do not influence the crystal phase being formed. Although the damage to porous materials is most likely created by mirabilite, it must be noted that this crystalline phase seems not to be formed directly during drying. However, in order to create damage, there needs to be a transformation to mirabilite. This additional transformation from already heptahydrate (or thenardite) has to be taken into account and is at this moment missing in studies on salt crystallization [24,25].

\section{Conflict of interest}

None declared.

\section{Acknowledgment}

This research was supported by the Dutch Technology Foundation (STW), project 06752: Salt Weathering of porous building materials.

\section{References}

[1] I.S. Evans, Salt crystallization and rock weathering: a review, Rev. Geomorphologie Dynamique 19 (1970) 153-177.

[2] A.S. Goudie, H. Viles, Salt Weathering Hazards, Chichester, 1997.

[3] E. Doehne, Salt Weathering: A Selective Review. Natural Stone, Weathering Phenomena, Conservation Strategies and Case Studies, Geological Society Special Publication 205, London, 2003.

[4] J. Flatt, Salt damage in porous materials: how high supersaturations are generated, J. Cryst. Growth 242 (2002) 435-454.

[5] C.W. Correns, Growth and dissolution of crystals under linear pressure, Disc. Faraday Soc. 267 (1949) 271

[6] J. Flatt, G.W. Scherer, M. Steiger, A commented translation of the paper by C.W. Correns and W. Steinborn on crystallization pressure, Environ. Geol. 52 (2007) 187-203.

[7] M. Steiger, S. Asmussen, Crystallization of sodium sulfate phases in porous materials: the phase diagram $\mathrm{Na}_{2} \mathrm{SO}_{4}-\mathrm{H}_{2} \mathrm{O}$ and the generation of stress, Geochim. Cosmochim. Acta 72 (2008) 4291-4306.

[8] H. Lövel, Observations sur la sursaturation des dissolutions salines - premier memoire, Ann. Chim. Phys. 29 (1850) 62-127.

[9] H. Hartley, B.M. Jones, G.A. Hutchison, The spontaneous crystallization of sodium sulfate solutions, Chem. Soc. 93 (1908) 825-833.

[10] L.C. de Coppet, Recherches sur la surfusion et la sursaturation, Ann. Chim. Phys. 10 (1907) 457.

[11] W. Ostwald, Studies upon the forming and changing solid bodies, W. Z. Phys. Chem. 22 (1897) 289-330.

[12] L.A. Rijniers, H.P. Huinink, L. Pel, K. Kopinga, Experimental evidence of crystallization pressure inside porous media, Phys. Rev. Lett. 94 (2005) 075503.

[13] A. Liversidge, On supersaturated saline solutions, Proc. R. Soc. Lond. 20 (1872) 497-507.

[14] T.A. Saidov, N. Bonn, L. Pel, Crystallization of sodium sulfate of hydrophilic/ hydrophobic surfaces during drying: an NMR study, EPL 102 (2013). 28003-p6.

[15] H. Derluyn, T.A. Saidov, R.M. Espinosa-Marzal, L. Pel, G.W. Scherer, Sodium sulfate heptahydrate I: the growth of single crystals, J. Cryst. Growth 329 (2011) 44-51.

[16] T.A. Saidov, L. Pel, R.M. Espinosa-Marzal, G.W. Scherer, Nucleation of sodium sulfate heptahydrate on mineral substrates studied by nuclear magnetic resonance, J. Cryst. Growth 338 (2012) 166-169.

[17] H.P. Huinink, L. Pel, M.A.J. Michels, How ions distribute in a drying porous medium - a simple model, Phys. Fluids 14 (2002) 1389-1395.

[18] T.A. Saidov, Sodium sulfate heptahydrate in weathering phenomena of porous materials (Ph.D. thesis), Eindhoven University of Technology, 2012.

[19] K. Kopinga, L. Pel, One dimensional scanning of moisture in porous materials with NMR, Rev. Sci. Instrum. 65 (1994) 3581-3673. 
[20] K. Linnow, A. Zeunert, M. Steiger, Investigation of sodium sulfate phase transition in a porous material using humidity - and temperature-controlled X-ray diffraction, Anal. Chem. 78 (2006) 4683-4689.

[21] L. Pel, H. Huinink, K. Kopinga, Ion transport and crystallization in inorganic building materials as studied by nuclear magnetic resonance, Appl. Phys. Lett. 81 (2002) 2893-2895.

[22] L. Pel, H. Huinink, K. Kopinga, R.P.J. van Hees, O.C.G. Adan, Efflorescence pathway diagram: understanding salt weathering, Constr. Build. Mater. 18 (2004) 309-313.
[23] J. Petkovic, H.P. Huinink, L. Pel, K. Kopinga, Diffusion in porous building materials with high internal magnetic field gradients, J. Mag. Reson. 167 (2004) 97-106.

[24] M. Koniorczyk, Salt transport and crystallization in non-isothermal, partially saturated porous materials considering ions interaction model, Int. J. Heat Mass Transfer 55 (2012) 665-679.

[25] C. Rodriguez-Navarro, E. Doehne, E. Sebastian, How does sodium sulfate crystallize? Implications for the decay and testing of building materials, Cem. Concr. Res. 30 (2000) 1527-1534. 